\title{
錠剂の粉砕末を原料とした院内製剤プレドニゾロン坐剤の放出制御
}

辰見明俊, ${ }^{*}, a$ 織田祥子, ${ }^{b}$ 中元智子, ${ }^{a}$ 村岡玲子, ${ }^{a}$ 高橋佳子, ${ }^{a}$ 田中邦佳, ${ }^{a}$ 志方敏幸, ${ }^{a}$ 辰己純代, ${ }^{a}$ 多河典子, ${ }^{b}$ 小林吉晴, ${ }^{b}$ 湞口常男, ${ }^{a}$ 門林宗男 ${ }^{a}$

\section{Release Control of Prednisolone from Suppository Prepared Using Powder of Pulverized Tablet}

\author{
Akitoshi TAtsumi, ${ }^{*, a}$ Shoko Oda, ${ }^{b}$ Tomoko NaKamoto, ${ }^{a}$ Reiko MURAOKa, ${ }^{a}$ \\ Yoshiko TAKAHASHI, ${ }^{a}$ Kuniyoshi TANAKA, ${ }^{a}$ Toshiyuki SHIKATA, ${ }^{a}$ Sumiyo TATSUMI, ${ }^{a}$ \\ Noriko TAGAWA, ${ }^{b}$ Yoshiharu KoBAYASHI, ${ }^{b}$ Tsuneo HAMAGUCHI, ${ }^{a}$ and Muneo KADOBAYASHI ${ }^{a}$ \\ ${ }^{a}$ Department of Pharmacy, The Hospital of Hyogo College of Medicine, 1-1 Mukogawa-cho, \\ Nishinomiya City 663-8501, Japan and bepartment of Medical Biochemistry, \\ Kobe Pharmaceutical University, 4-19-1 Motoyamakita-machi, \\ Higashinada-ku, Kobe 658-8558, Japan
}

(Received December 2, 2007; Accepted January 15, 2008)

\begin{abstract}
Prednisolone suppositories have been used successfully for the treatment of ulcerative colitis in hospital settings. However, the raw material of prednisolone suppository, JP prednisolone powder (JP Powder), was recently removed from the market. Therefore we studied the effects of raw material and suppository base on the release of prednisolone suppository for the purpose of designing a new suppository with similar effects to those of suppository prepared using JP powder (old suppository). New suppositories consisting of the powder of pulverized tablet as raw material and Witepsol H-15 and Witepsol E-75 as suppository base were prepared according to the fusion method. Suppository release test was performed by reciprocating dialysis tube method with tapping (RDT method) and dialysis tubing method (DT method). Both RDT method and DT method were performed using a suppository dissolution apparatus (modified JP disintegration apparatus) and a JP15 paddle apparatus, respectively. The test fluid was $50 \mathrm{mM}$ phosphate buffer solution ( $\mathrm{pH} 7.4$ ) maintained at $37 \pm 0.5^{\circ} \mathrm{C}$. The results of release test by RDT method were similar to those of DT method. Release rate of prednisolone from the new suppository was much faster than that of old suppository. The addition of Witepsol E-75 to new suppository base markedly delayed the release of prednisolone from the new suppository. Release rate of prednisolone from the new suppository, consisting of pulverized tablet and Witepsol H-15 and Witepsol E-75 (76:24), corresponded well with that of the old suppository. It was suggested that this suppository could be used as incoming preparation of suppository prepared using JP powder.
\end{abstract}

Key words_— prednisolone; suppository; release test; Witepsol; in-hospital preparation

\section{緒言}

潰瘍性大腸炎は結腸と直腸で繰り返される炎症性 で潰瘍性の疾患であり, クローン病とともに炎症性 腸疾患と呼ばれている. ${ }^{1}$ 臨床的には粘血便を主徵 とし，再燃・緩解を繰り返しながら慢性に経過する 症例が多く，長期経過においては大腸がんの合併が 問題となる。薬物療法には，アミノサリチル酸化合 物，副腎皮質ホルモン及び免疫抑制剂などが使用さ

$a$ 兵庫医科大学病院薬剤部, $b$ 神戸薬科大学病態生化学 研究室

*e-mail: yktatua@hyo-med.ac.jp
れている，特に，副腎皮質ホルモンは潰瘍性大腸炎 における活動期に最も有効な薬剂とされている。 ${ }^{2)}$ しかし，経口及び静脈内投与による副腎皮質ホルモ ン剂特有の全身性副作用の発現が問題となってい る。そのため, 坐剤や注腸剂を用いた局所療法が欧 米を中心に古くから行われてきた.

プレドニゾロンは，合成副腎皮質ホルモン剂で, 経口，点滴及び注腸投与により潰瘍性大腸炎に汎用 されている．また，潰瘍性大腸炎へのプレドニゾロ ンを主薬とする坐剂の有用性が示されている. ${ }^{3-5)}$ このことから, 兵庫医科大学病院薬剤部では, 1981 年より診療科の依頼を受けて院内製剂として，直腸 
への局所作用を期待したプレドニゾロン坐剤を調製 し，これらの炎症性疾患患者に提供してきた。現 在, プレドニゾロン坐剤 $10 \mathrm{mg}$ を約 10000 個／ 年，プレドニゾロン坐剤 $20 \mathrm{mg}$ を約 5000 個／年調 製しており，当院の炎症性腸疾患の薬物療法を支え ている。このプレドニゾロン坐剤は，全国の他の医 療機関においても院内製剤として調製され使用され ている. ${ }^{6)}$

最近，原料となる「日局」プレドニゾロン末（こ れ以降，日局末と略す）が販売中止となり，プレド ニゾロン坐剤の調製が困難となったことから，これ に代わる原料を用いて新たなプレドニゾロン坐剤の 調製が必要となった。そこで，市販錠を粉砕し粉末 （これ以降，錠剂粉砕末と略す）としたものを原料 として用いることが考えられるが，錠剤粉砕末を原 料とした坐剂の情報はない. 他の薬物についても錠 剂粉砕末を原料とした坐剂の情報もない.

そこで今回, 現在供給しているプレドニゾロン坐 剂と同等な薬物放出性を示す坐剂の調製を目的とし て，錠剤粉砕末を原料とするプレドニゾロン坐剤の 院内製剂化の検討を行つた。 まず，予備実験として 原料末の溶出試験を行つたところ, 日局末に比べ錠 剂粉砕末からの主薬の溶出は非常に速いことが分か った。このことから，従来調製していた日局末を原 料とする坐剂と同等の放出性を示す坐剂を調製する ための製剤学的な検討の必要性が示唆された。そこ で，1つの手法として，基剤に融点の高い他の基剤 を配合するなど坐剤からの主薬の放出性制御に着目 し，錠剤粉砕末を原料とした坐剂の最適な基剤の混 合割合の処方探索を，in vitro での坐剂からの主薬 の放出速度と混合割合の関係から求める検討を行っ た。なお，対照として，日局末，試薬末を原料とし た坐剤を用いた。

\section{方法}

1. 試料 プレドニゾロン坐剤の原料には「日 局」プレドニゾロン末 (Lot No. 5Z28, 丸石製薬 (秼)，生化学用プレドニゾロン [Lot No. EWJ5552, 和光純薬秼］，プレドニン®錠 $5 \mathrm{mg}$ [Lot No. 5124, 塩野義製薬秼］を用い，坐剂の基剤には Witepsol H-15 [Lot No. 6531，丸石製薬株］及び Witepsol E-75 [Lot No. 6509，丸石製薬侏］を用いた。 その 他の試薬には市販の特級品を用いた.
2. 坐剂の調製 プレドニゾロン坐剂の調製は すべて熔融法にて行った。 すなわち，40-50 ${ }^{\circ} \mathrm{C} て ゙$ 加 温熔融した Witepsol H-15 単独又は Witepsol H-15 と Witepsol E-75 の各種割合 $(80: 20,75: 25$, $70: 30,60: 40,50: 50$ ) の混合物に, 原料として, 75 号の篩で篩過した従来の「日局」プレドニゾロ ン末，生化学用プレドニゾロン（これ以降，試薬末 と略す)，あるいは市販錠の粉砕後 200 号の篩で篩 過したプレドニン®錠の粉砕末を加えて攪拌後, プ ラスチック製坐剂型枠に注入し，室温に静置し固化 させた，調製した坐剤は試験に供するまで冷暗所で 保存した。なお，坐剤 1 個（2 g) 中にはプレドニ ゾロン $10 \mathrm{mg}$ 相当量を含有するよう調製した。今 回実験に用いた各種プレドニゾロン坐剤の組成を Table 1 に示す.

3. 質量偏差試験 坐剂型枠から取り出した各 坐剂 10 個の重量を電子天秤 (AJ1502, METTLER) で測定し，平均重量及び標準偏差を算出した。

4. 含量均一性試験 メスフラスコに坐剂 1 個 を取り， $60-70{ }^{\circ} \mathrm{C}$ に加温したメタノール：水 $(1: 1)$ 混液 $80 \mathrm{ml}$ を加えて溶解し, 十分に攪拌後, 1 時間 冷却し基剤を固化させた。室温に戻し，さらにメ夕 ノール：水（1：1）溶液を加えて全量 $100 \mathrm{ml}$ とし, ろ過した。そのろ液をメタノール：水 $(1: 1)$ 溶液 で 10 倍に希釈後, 紫外部分光光度計 (U2800 形分 光光度計, 陎日立ハイテクノロジーズ）により波長 $242 \mathrm{~nm}$ における吸光度を測定し, あらかじめ作成 した検量線から主薬の含有量を算出した.

5. 原料末及び錠剤粉砕末の溶出試験 溶出試 験器 [NTR-1000, 富山産業秼］を用い, 日局 15 の溶出試験のパドル法に従って行った。試験液には 0.05 M リン酸緩衝液（pH 7.4） $900 \mathrm{ml}$ を用い, 溶 出試験液の温度は $37 \pm 0.5^{\circ} \mathrm{C}$ に維持した。 パドルの 回転数は $100 \mathrm{rpm}$ とした. 試験開始後経時的に溶 出試験液 $5 \mathrm{ml}$ を採取し, 直ちにメンブランフィル ター $(0.45 \mu \mathrm{m})$ でろ過した。 その後, 同量の試験 液を補充した。この試料の吸光度を紫外部吸光度測 定法（ $\lambda=242 \mathrm{~nm} ）$ により測定し, あらかじめ作成 した検量線を基に定量した。

\section{6. 坐剂放出試験}

6-1. Reciprocating dialysis tube method with tapping（RDT 法）坐剂放出試験は理研式坐剂溶出 試験器 [HZ-11D，宮本理研工業侏］を用い，Itoh 
Table 1. Raw Material and Composition of Suppository Base of Prednisolone Suppositories

\begin{tabular}{cll}
\hline \hline Formulation & \multicolumn{1}{c}{ Raw material } & Base \\
\hline A & JP prednisolone powder & Witepsol H-15: Witepsol E-75=100:0 \\
B & Prednisolone reagent powder & Witepsol H-15: Witepsol E-75=100:0 \\
C & Pulverized prednisolone tablet & Witepsol H-15: Witepsol E-75=100:0 \\
D & Pulverized prednisolone tablet & Witepsol H-15: Witepsol E-75=80:20 \\
E & Pulverized prednisolone tablet & Witepsol H-15: Witepsol E-75=75:25 \\
F & Pulverized prednisolone tablet & Witepsol H-15: Witepsol E-75=70:30 \\
G & Pulverized prednisolone tablet & Witepsol H-15: Witepsol E-75=60:40 \\
H & Pulverized prednisolone tablet & Witepsol H-15: Witepsol E-75=50:50
\end{tabular}

et al. の方法7) に従つて行つた. $20 \mathrm{~cm}$ に切つた透析 膜（Spectra/Por ${ }^{\circledR} 6$ Membrane, MWCO: 50000, Spectra Laboratories, Inc.) はあらかじめ精製水に 浸し使用時によく洗浄した. フィルムスクイージー で水を切った透析膜に坐剂 1 個を入れ，一方の端を ステンレス製のクローサーで締結し， $37 \pm 0.5^{\circ} \mathrm{C}$ の $0.05 \mathrm{M}$ リン酸緩衝液（pH 7.4） $1000 \mathrm{ml}$ の坐剂放出 試験液に設置した。上下運動は 30 回/分とし，試験 開始後経時的に試料液 $5 \mathrm{ml}$ を採取し，同量の試験 液を補充した。試料液中の主薬の含有量は紫外部吸 光度測定法 $(\lambda=242 \mathrm{~nm})$ により求めた.

\section{6-2. Dialysis tubing method（DT 法）坐剂放} 出試験は, 溶出試験器 [NTR-1000, 富山産業侏］ を用いて, Aoyagi et al.の方法8)に従って行った. 透析膜（上述）を長さ $17 \mathrm{~cm}$ に切断し，あらかじ め精製水に浸し使用時によく洗浄した. フィルムス クイージーで水を切った透析膜に坐剤 1 個を入れ, 一方の端をステンレス製のクローサーで締結した. 試験液に RDT 法と同様の試験液 $900 \mathrm{ml}$ を用い, パドルの攪拌速度は $50 \mathrm{rpm}$ として, 試験液の採取 及び主薬の含有量の測定は RDT 法と同様に行った.

\section{7. 坐剂の融解時間の測定 試験液に理研式坐} 剂溶出試験器 [HZ-11D, 宮本理研工業侏］を用い, 上述の RDT 法の場合と同様に行った。試験液の温 度を $36{ }^{\circ} \mathrm{C}, 37{ }^{\circ} \mathrm{C}$ あるいは $38{ }^{\circ} \mathrm{C}$ としたときの，錠 剂粉砕末を原料にした各種坐剂が完全に融解する時 間を測定した。

8. 薬物速度論的解析 坐剂放出試験における 3 時間までのプレドニゾロンの溶出量-時間曲線か ら, Tanigawara et al.のモーメント解析法9)を用い て, 累積溶出量（AD）及び平均溶出時間（MDT） を算出し，また，各サンプリング時間における放出
速度の平均值を求めた。

9. 統計処理 基剤の混合割合とプレドニゾロ ン坐剤からの主薬の放出速度の関係は単回帰分析に より行った. 各坐剂の放出挙動のデータ及び溶出パ ラメータの平均值の有意差検定は, Student $の ~ t$ 検 定あるいは一元配置分散分析と Tukey の多重比較 検定により行った。いずれも危険率 $5 \%$ 以下で有意 差ありと判定した.

\section{結果}

1. プレドニゾロン坐剤の質量偏差試験 $\mathrm{Ta}$ ble 2 は，種々のプレドニゾロン坐剤について，そ れぞれ 10 個の坐剤の重量の平均值とその変動係数 を示している。調製した各種プレドニゾロン坐剤の 重量は 2.00-2.01 g の範囲にあり，それらの変動係 数は $0.32 \%$ 以下であり, 均一な重量の坐剤調製が できることが分かった.

2. プレドニゾロン坐剤の含量均一性試験 種 々のプレドニゾロン坐剤における主薬含量の定量結 果を Table 2 に示す。各種坐剂の主薬の含量は, 10.03-10.29 mg の範囲であり, それらの変動係数 も $1.91 \%$ 以下で含量の均一性が確保されていると 判断された。

3. プレドニゾロン坐剤の原料末の溶出試験 種々の原料末からの主薬の溶出挙動を Fig. 1 に 示す．日局末及び試薬末からの主薬の溶出挙動はほ ぼ同様であった。一方，錠剤粉砕末からの主薬の放 出は速かった。特に，溶出試験開始初期において， 錠剤粉砕末からの主薬の溶出速度は日局末や試薬末 のものに比べて速く，溶出試験開始 10 分後の主薬 の溶出量は日局末のものに比べ 1.8 倍を示した.

4. プレドニゾロン坐剤の放出試験 製剤 $\mathrm{A}$, 
Table 2. Suppository Weight and Content of Prednisolone Suppository

\begin{tabular}{cccccc}
\hline \hline \multirow{2}{*}{ Formulation } & \multicolumn{2}{c}{ Suppository weight $(\mathrm{g})$} & & \multicolumn{2}{c}{ Content $(\mathrm{mg})$} \\
\cline { 2 - 3 } \cline { 5 - 6 } & Mean \pm S.D. & C.V. $(\%)$ & & Mean \pm S.D. & C.V. $(\%)$ \\
\hline A & $2.01 \pm 0.00$ & 0.21 & & $10.14 \pm 0.13$ & 1.32 \\
B & $2.00 \pm 0.01$ & 0.28 & & $10.05 \pm 0.15$ & 1.45 \\
C & $2.00 \pm 0.01$ & 0.28 & & $10.03 \pm 0.19$ & 1.91 \\
D & $2.00 \pm 0.00$ & 0.21 & & $10.29 \pm 0.15$ & 1.49 \\
E & $2.00 \pm 0.00$ & 0.21 & & $10.16 \pm 0.10$ & 1.00 \\
F & $2.00 \pm 0.01$ & 0.26 & & $10.15 \pm 0.09$ & 0.89 \\
G & $2.00 \pm 0.01$ & 0.32 & & $10.14 \pm 0.06$ & 0.56 \\
H & $2.00 \pm 0.00$ & 0.16 & & $10.25 \pm 0.06$ & 0.60 \\
\hline
\end{tabular}

Each value represents the mean \pm S.D. $(n=10)$.

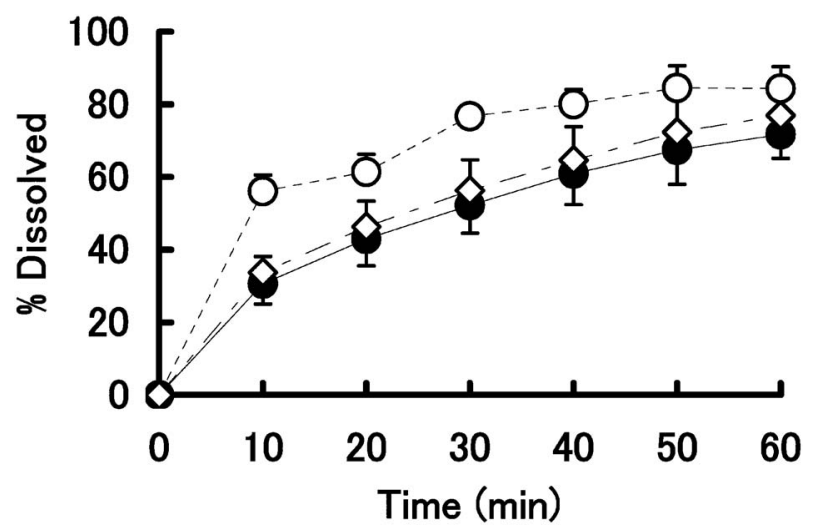

Fig. 1. Dissolution Profiles of Prednisolone from Raw Materials Powder

O: JP Powder, $\diamond$ : Reagent Powder, $\bigcirc$ : Pulverized tablet, Each point represents the mean \pm S.D. $(n=3)$.

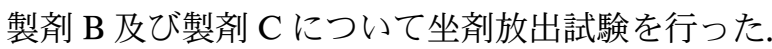
RDT 法による坐剂放出試験の結果を Fig. 2 及び Table 3 に，DT 法による坐剂放出試験の結果を Fig. 3 及び Table 4 に示す. RDT 法において製剤 C からの主薬の放出量と速度は 3 製剤間の中で最も多 く，かつ最も速かった。製剤 Cの AD は $9.7 \mathrm{mg}$ と 最も高く, MDTは $0.73 \mathrm{~h}$ と最も短く, 平均放出速 度は $4.93 \mathrm{mg} / \mathrm{h}$ と最も速かった。また，製剤 $\mathrm{A}$ と 製剂 B からの主薬の放出挙動は両者間で差違を認 めなかった。一方，DT 法で坐剤からの放出挙動を 検討した結果， 3 製剤からの主薬の放出量と放出速 度は RDT 法でのものに比べ大きく低下した。しか し，DT 法における 3 製剤間の挙動は RDT 法と同 様であり, 製剤 Cからの主薬の放出量と放出速度 は他の 2 製剤のものより多くかつ速かった。

5. プレドニゾロン坐剤からの主薬の放出挙動に

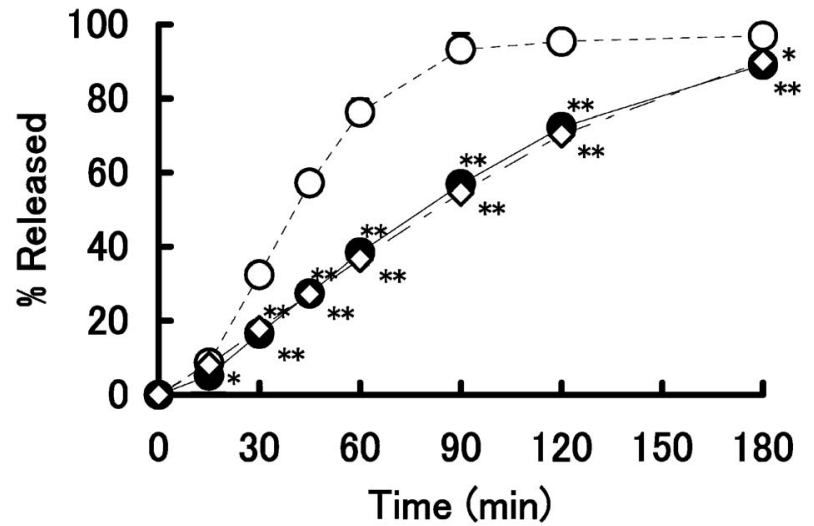

Fig. 2. Effect of Raw Material on the Release of Prednisolone from Suppository Using RDT Method

๑: Formulation A, $\diamond$ : Formulation B, $\bigcirc$ : Formulation C, Each point represents the mean \pm S.D. $(n=3) .{ }^{*} p<0.05,{ }^{* *} p<0.01$ compared with formulation C (Tukey's test).

及ぼす基剤の混合割合の検討 RDT 法を用い て, 錠剂粉砕末坐剂からの主薬の放出挙動に及ぼす 基剤の混合割合（Witepsol H-15 と Witepsol E-75 の混合物）の影響について検討した結果を Fig. 4 と Table 5 に示す。 その結果, 坐剤の基剤組成比で 20\%の Witepsol E-75 を添加した製剤 D からの主薬 の放出量と放出速度は無添加の製剂 $\mathrm{C}$ のものに比 ベて大きく低下し，製剤 D の AD，MDT 及び平均 放出速度は製剂 C のものに比べてそれぞれ約 14\% の減少，約 $44 \%$ の増加及び約 $36 \%$ の減少を示し た. さらに, Witepsol E-75 の割合を増加させるに 従って錠剂粉砕末坐剂からの主薬の放出の量と速度 は減少した。ここで, 基剤の混合割合とプレドニゾ ロン坐剤からの主薬の放出速度の関係を検討した.

Figure 5 は, 溶出パラメータのうちの平均放出速度 を縦軸に, Witepsol E-75 の混合割合を横軸にプロ 
Table 3. Dissolution Parameters for Prednisolone from Suppositories Prepared Using Various Raw Material Using RDT Method

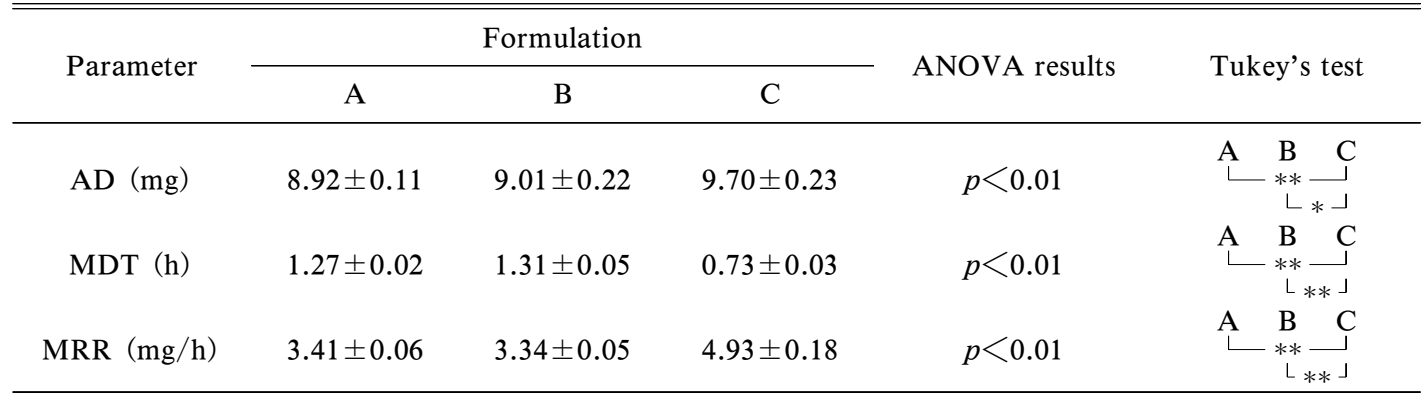

Each value represents the mean \pm S.D. $(n=3)$. AD: Cumulative amount of drug released in solution in 3 h. MDT: Mean dissolution time. MRR: Mean release rate. ${ }^{*} p<0.05,{ }^{* *} p<0.01$.

Table 4. Dissolution Parameters for Prednisolone from Suppositories Prepared Using Various Raw Material Using DT Method

\begin{tabular}{|c|c|c|c|c|c|c|}
\hline \multirow{2}{*}{ Parameter } & \multicolumn{3}{|c|}{ Formulation } & \multirow{2}{*}{ ANOVA results } & \multirow{2}{*}{\multicolumn{2}{|c|}{ Tukey's test }} \\
\hline & A & B & $\mathrm{C}$ & & & \\
\hline $\mathrm{AD}(\mathrm{mg})$ & $3.35 \pm 0.34$ & $3.59 \pm 0.32$ & $4.45 \pm 0.22$ & $p<0.01$ & & $\underset{* *}{\mathrm{~B}} \underset{*}{\llcorner} \underset{\mathrm{C}}{\mathrm{C}}$ \\
\hline MDT（h） & $1.39 \pm 0.03$ & $1.36 \pm 0.01$ & $1.31 \pm 0.03$ & $p<0.05$ & & $\underset{* *}{\mathrm{~B}} \stackrel{\mathrm{C}}{\llcorner} \underset{*}{\llcorner}\lrcorner$ \\
\hline $\operatorname{MRR}(\mathrm{mg} / \mathrm{h})$ & $1.19 \pm 0.12$ & $1.30 \pm 0.12$ & $1.67 \pm 0.07$ & $p<0.01$ & & $\underset{* *}{\mathrm{~B}} \underset{\mathrm{*}_{* *}}{\mathrm{C}}$ \\
\hline
\end{tabular}

Each value represents the mean \pm S.D. $(n=3)$. AD: Cumulative amount of drug released in solution in $3 \mathrm{~h}$. MDT: Mean dissolution time. MRR: Mean release rate. ${ }^{*} p<0.05,{ }^{* *} p<0.01$.

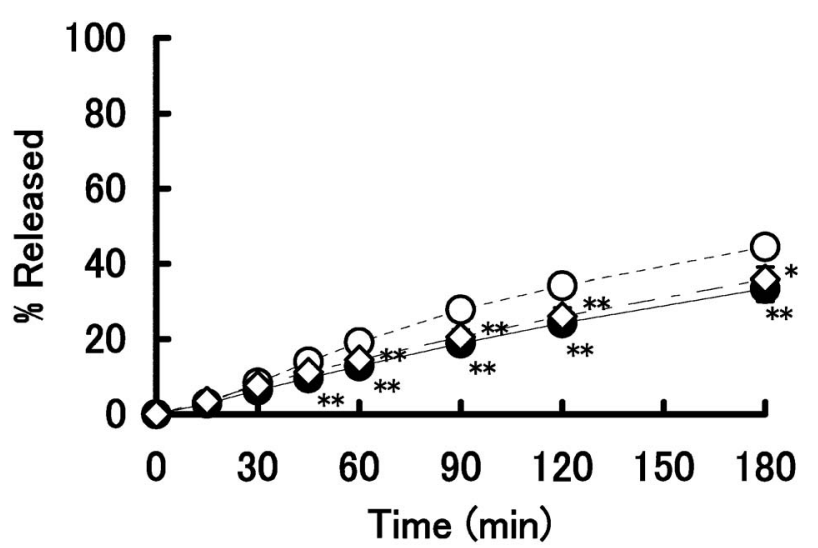

Fig. 3. Effect of Raw Material on the Release of Prednisolone from Suppository Using DT Method

-: Formulation A, $\diamond$ : Formulation B, $\bigcirc$ : Formulation C, Each point represents the mean \pm S.D. $(n=3) .{ }^{*} p<0.05,{ }^{* *} p<0.01$ compared with formulation C (Tukey's test).

ットしたものである。Witepsol E-75 の混合割合を 独立変数とし回帰分析を行つた結果, 回帰関数 $\mathrm{Y}=$ $-0.0407 \mathrm{X}+4.485$, 決定係数 0.8182 で回帰の有意 性（ $p<0.01 ）$ が示された.

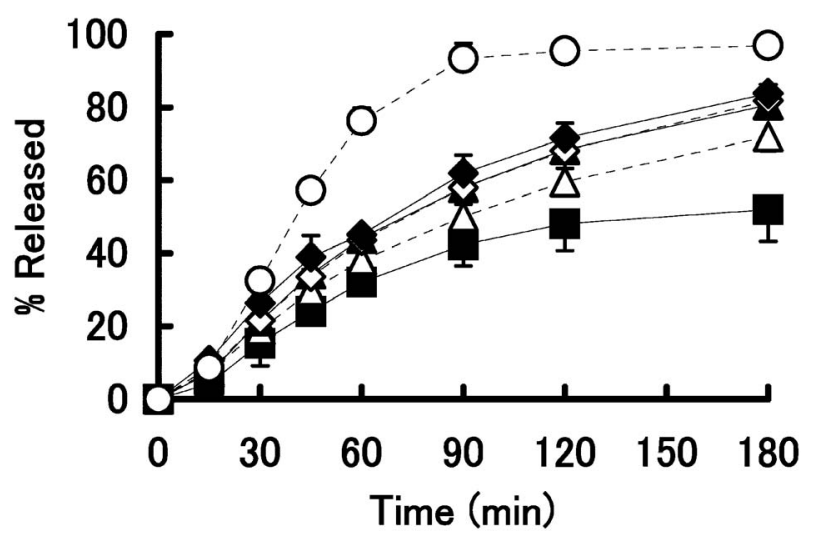

Fig. 4. Effect of Suppository Base on the Release of Prednisolone from Suppository Using RDT Method

O: Formulation C, $\diamond$ : Formulation D, $\diamond$ : Formulation E, $\boldsymbol{\Delta}$ : Formulation F, $\triangle$ : Formulation G, $\boldsymbol{\square}$ : Formulation $\mathrm{H}$, Each point represents the mean \pm S.D. $(n=3)$.

次に, 坐剂の融解時間に及ぼす基剤及び温度の影 響を RDT 法で検討した。Table 6 は製剤 $\mathrm{C}$ ，製剂 E 及び製剂 $\mathrm{H}$ の融解時間に及ぼす試験液温度の影 響の結果を示している。すずての製剤において，試 
Table 5. Dissolution Parameters for Prednisolone from Suppositories Prepared Using Powder of Pulverized Tablet Using RDT Method

\begin{tabular}{cccc}
\hline \hline Formulation & AD $(\mathrm{mg})$ & MDT $(\mathrm{h})$ & MRR $(\mathrm{mg} / \mathrm{h})$ \\
\hline D & $8.38 \pm 0.24$ & $1.05 \pm 0.09$ & $3.62 \pm 0.28$ \\
E & $8.18 \pm 0.22$ & $1.13 \pm 0.03$ & $3.39 \pm 0.13$ \\
F & $8.07 \pm 0.32$ & $1.11 \pm 0.05$ & $3.39 \pm 0.22$ \\
G & $7.20 \pm 0.39$ & $1.14 \pm 0.05$ & $2.97 \pm 0.12$ \\
H & $5.20 \pm 0.87$ & $0.95 \pm 0.12$ & $2.34 \pm 0.30$ \\
\hline
\end{tabular}

Each value represents the mean \pm S.D. $(n=3)$. AD: Cumulative amount of drug released in solution in $3 \mathrm{~h}$. MDT: Mean dissolution time. MRR: Mean release rate.

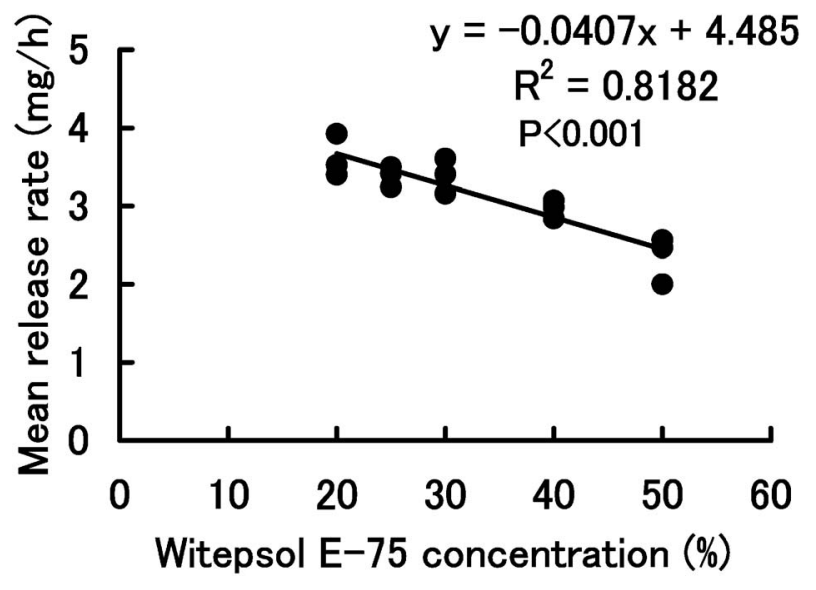

Fig. 5. Relationship between Mixture of Suppository Base and Release Rate of Prednisolone from Suppository

験液温度の上昇により坐剤の融解時間は短縮した. また，坐剤中のWitepsol E-75 の割合を増加させる ことにより坐剤の融解時間は延長することが分かっ た.

6. 製剂 $\mathbf{A}$ からの主薬の放出速度と同等なプレ ドニゾロン坐剤の調製＼cjkstart坐剤からの主薬の放出速 度と Witepsol E-75 の混合割合の回帰式（Fig. 5） に，製剤 A の平均放出速度の值（Table 3）を代入 すると，Witepsol E-75 の混合割合が 26\%であるこ とが算出された。そこで，錠剤粉砕末を原料とし， 基剂に Witepsol H-15：Witepsol E-75=74：26 を 用いて製剤 I を調製し，RDT 法を用いて坐剂放出 試験を検討した。その結果を Fig. 6 と Talbe 7 に示 す。製剤 I からの主薬の放出挙動は製剤 A のもの に良く近似しており，両製剤間での放出量の各デー 夕の差異はわずかであったが，有意の差を認めた. また，その溶出パラメータもほぼ同じであった。
Table 6. Melting Time of Various Prednisolone Suppositories Consisting of Powder of Pulverized Tablet and Mixed Base

\begin{tabular}{crcc}
\hline \hline \multirow{2}{*}{ Formulation } & \multicolumn{3}{c}{ Melting time (min) } \\
\cline { 2 - 4 } & \multicolumn{1}{c}{$36^{\circ} \mathrm{C}^{a)}$} & $37^{\circ} \mathrm{C}^{a)}$ & $38^{\circ} \mathrm{C}^{a)}$ \\
\hline $\mathrm{C}$ & $8.0 \pm 0.4$ & $5.8 \pm 0.2$ & $4.4 \pm 0.1$ \\
$\mathrm{E}$ & $14.1 \pm 0.3$ & $7.0 \pm 0.2$ & $5.3 \pm 0.1$ \\
$\mathrm{H}$ & $21.7 \pm 0.6$ & $9.5 \pm 0.1$ & $6.6 \pm 0.2$ \\
\hline
\end{tabular}

Each value represents the mean \pm S.D. $(n=3) . a)$ : Temperatures of test solutions.

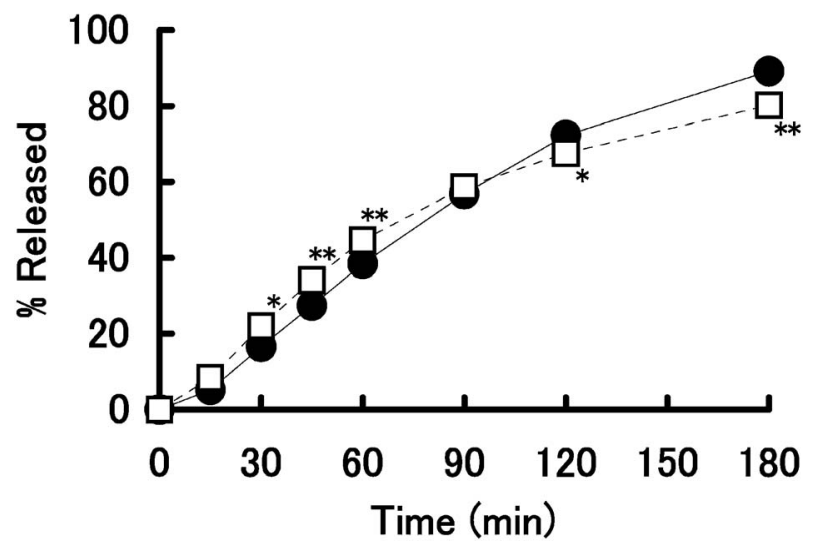

Fig. 6. Release Profiles of Prednisolone from Suppository Consisting of Powder of Pulverized Tablet and Mixed Base (Witepsol H-15: Witepsol E-75=74:26)

๑: Formulation A, $\square$ : Formulation I, Each point represents the mean \pm S.D. $(n=3) .{ }^{*} p<0.05,{ }^{* *} p<0.01$ compared with formulation A (Student's $t$ test).

Table 7. Dissolution Parameters for Prednisolone from Suppository Consisting of Powder of Pulverized Tablet and Mixed Base (Witepsol H-15: Witepsol E-75=74:26)

\begin{tabular}{|c|c|c|c|}
\hline Formulation & $\mathrm{AD}(\mathrm{mg})$ & MDT (h) & $\operatorname{MRR}(\mathrm{mg} / \mathrm{h})$ \\
\hline I & $8.02 \pm 0.19$ & $1.09 \pm 0.01$ & $3.39 \pm 0.07$ \\
\hline
\end{tabular}

Each value represents the mean \pm S.D. $(n=3)$. AD: Cumulative amount of drug released in solution in $3 \mathrm{~h}$. MDT: Mean dissolution time. MRR: Mean release rate.

今回，われわれは，市販錠剤の粉砕末を原料に用 いて従来の日局末坐剂と製剤学的に同等な坐剂の製 剂化を目指してプレドニゾロン坐剂の処方検索を検 討した．新たなプレドニゾロン坐剤の原料を探索す る条件としては，医薬品の中から選択することであ つた，医薬品としては，散剤 $(1 \%)$, 錠剤, 注射剤 がある、散剤は $1 \%$ であるため嵩が多くなり坐剤の 
調製が困難であった。注射剂では，アンプルカット 時に混入するガラス片の問題，並びに成分がプレド ニゾロンコハク酸エステルナトリウムの水溶性の物 性に対して，日局末のプレドニゾロンは水に難溶性 であるため，坐剂からの主薬の放出挙動が両成分間 において大きく異なることが予想されること，そし て薬価が高いといった問題があったそそこで，錠剤 を粉砕した粉末を原料に利用できるのではないかと 考え，錠剤粉砕末を用いた坐剂の院内製剂化を検討 した.

坐剂の製剂学的同等性の指標として坐剂の放出試 験を用いた。坐剤の放出試験法には，Yamazaki et al. が報告10)している in vitro デー夕と in vivo デー 夕との相関が特によい RDT 法及び比較的よい DT 法の 2 つの方法を選択した，両試験法において，錠 剂粉砕末を原料として調製した坐剂からの主薬の放 出性は，対照に用いた日局末坐剤や試薬末坐剂のも のに比べ速かった。この原因は，原料末の溶出試験 結果が示すように，錠剤粉砕末からの主薬の溶出速 度は日局末や試薬末のものに比べて著しく速いため であった。また，錠剤粉砕末からの主薬の溶出が速 かった原因は，錠剤に含有される親水性の乳糖など の賦形剂に起因しているものと考えられる。これら のことから，錠剂粉砕末坐剂は，従来品の日局末坐 剂よりも主薬の放出速度が速いため，主薬の直腸吸 収速度に変化を生じさせる可能性のあることを示唆 している。

錠剂粉䃅末坐剂からの主薬の放出速度が速いこと から，次にその放出速度の制御に関する検討を行っ た。すなわち，融点の異なる基剤の Witepsol H-15 （融点 $33.5-35.5{ }^{\circ} \mathrm{C}$ ） と Witepsol E-75（融点 37.0$\left.39.0{ }^{\circ} \mathrm{C}\right)$ を混合し，坐剂からの主薬の放出性に及 ぼす基剤混合割合の影響を，RDT 法により検討し た．鉈剂粉砕末の坐剂からの主薬の放出速度は，坐 剂基剂の Witepsol E-75 の混合割合が増加するにつ れて遅くなった。すなわち，融点の低い基剤と高い 基剂を混合した坐剂からの主薬の放出速度が遅くな る結果は, Hakata et al.,11) Iwata et al. ${ }^{12)}$ 及び Nakayama et al. ${ }^{13)}$ の報告と同様であった。また, 錠剂粉砕末の坐剂の融解時間について，人工膜とし て透析膜を用いて直腸内での坐剂の融解環境を考慮 した RDT 法により検討したところ，融解時間は Witepsol E-75 の混合割合の増加により遅延するこ
とが判つた。また，坐剤の融解時間が長くなるにつ れ，溶出パラメータの $\mathrm{AD}$ 及び平均放出速度が減 少した。このことから，坐剂中の主薬の放出に Witepsol E-75 が影響し，融解時間の調節により $\mathrm{AD}$ 及び平均放出速度を制御できることが示唆され た.

溶出パラメータと Witepsol E-75 の混合率の関係 を検討した結果，MDT と Witepsol E-75 の混合率 の間には良好な関係は認めなかった。しかしなが ら，プレドニゾロン坐剤からの主薬の放出速度と Witepsol E-75 の混合率との関係（Fig. 5）からは, Witepsol E-75 の混合割合を独立変数に，坐剤から の主薬の平均放出速度を従属変数にして回帰分析を 行った結果， $\mathrm{R}^{2}$ 值は 0.8182 と高く，回帰の有用性 が得られた。 $\mathrm{AD}$ と Witepsol E-75 の混合率の間に も回帰の有用性が示されたが， $\mathrm{R}^{2}$ 值は 0.8066 であ り坐剤からの主薬の平均放出速度との関係で得られ た $\mathrm{R}^{2}$ 值よりも低かった。 そこで，坐剤からの主薬 の平均放出速度と Witepsol E-75 の混合率の関係の 回帰直線を用いて最適な基剤の混合割合を算出する ことにした。その結果，Witepsol H-15 とWitepsol E-75 の混合比を $74: 26$ としたものが，日局末坐剂 の放出速度に匹敵することが推測された。そこで錠 剂粉砕末を原料とし，Witepsol H-15 と Witepsol E-75 の混合比を $74: 26$ とした坐剂を調製し放出試 験を行ったところ，その平均放出速度は $3.39 \mathrm{mg} / \mathrm{h}$ と日局末坐剂の平均放出速度とほぼ同等の值を示 し，最適な処方であることが確認できた。

今回の検討により，坐剤からの主薬の放出性とい う面においては，プレドニン®錠を原料に用いて融 点の異なる基剂を混合することで，主薬の放出制御 が可能になると考えられる。すなわち，基剤の混合 比が Witepsol H-15：Witepsol E-75=74：26のと き, 錠剂粉砕末の坐剂からの放出速度は従来品のプ レドニゾロン坐剤のものと同様になることが分かっ た。こうした製剤手法は，院内で依頼される他の坐 剂の薬物放出制御に対しても活用できると考えられ る.

\section{REFERENCES}

1) Kirsner J. B., Shorter R. G., N. Engl. J. Med., 306, 775-785 (1982).

2) Hanauer S. B., N. Engl. J. Med., 334, 841-848 
(1996).

3) Shiratori T., Tobe T., Shimoyama T., Fukui O., Kobayashi K., J. Jpn. Soc. Coloproctol., 33, 26-36 (1980).

4) Takahashi Y., Muto T., Kamiya J., Konishi F., Sawada T., Sugihara K., J. Jpn. Soc. Coloproctol., 35, 593-599 (1982).

5) Yamamura M., Ohama I., Shimoyama T., Sogo Rinsho, 36, 733-734 (1987).

6) Japanese Society of Hospital Pharmacists, “'Byouin-yakkyoku-seizai', 5th ed., Yakujinippo, Tokyo, 2003, p. 214.

7) Itoh S., Teraoka N., Matsuda T., Okamoto K., Takagi T., Oo C., Kao H. D., Eur. J. Pharm. Biopharm., 64, 393-398 (2006).

8) Aoyagi N., Kaniwa N., Takeda Y., Uchiyama M., Takamura F., Kido Y., Chem. Pharm.
Bull., 36, 4933-4940 (1988).

9) Tanigawara Y., Yamaoka K., Nakagawa T., Uno T., Chem. Pharm. Bull., 30, 1088-1090 (1982).

10) Yamazaki M., Itoh S., Tanabe K., Iyakuhin Kenkyu, 28, 232-240 (1997).

11) Hakata T., Iijima M., Kimura S., Sato H., Watanabe Y., Matsumoto M., Chem. Pharm. Bull., 41, 351-356 (1993).

12) Iwata M., Komiya S., Nakamura K., Kiuchi M., Andoh N., Hirahara F., Maitani Y., Takayama K., Drug Dev. Ind. Pharm., 27, 1039-1045 (2001).

13) Nakayama A., Aichi F., Kondo H., Sunada H., Yonezawa Y., Simada Y., Jpn. J. Pharm. Health Care Sci., 31, 802-807 (2005). 